\title{
TUNTUNAN AL QURAN MENGENAI PEMBINAAN TOLERANSI MELALUI KOMUNIKASI PADA ANAK DI KELUARGA
}

\author{
Waway Qadratulloh S* \\ Surel : waway@polban.ac.id
}

\begin{abstract}
The rise of intolerance, violence, bullying, extreme and radical actions in social life in society can not be separated from how the pattern of education and communication patterns in the family environment. In fact, in fact the Qur'an has led to his people to build a family that can pass on the good in it. This is in line with marriage as part of worship that has a function to keep maqashid al shari'ah..This article discusses the guidance of the Qur'an in communicating with children in the family environment. The established communication pattern is communication that can instill tolerant attitude on the child to be applied in individual life and social. There are six communication patterns that are guided in the Quran, namely qaulan baligha, qaulan sadida, qaulan karima, qaulan maysura, qaulan ma'rufa, and qaulan maysura. The six communication patterns are characteristic of Rabbani, Humane, Universal, Balanced, and Realistic.
\end{abstract}

Keywords: communication, tolerance, guidance of the Qur'an

*Waway Qadratulloh S., S.Pd., M.Ag. Dosen Politeknik Negeri Bandung 


\section{PENDAHULUAN}

A rtikel ini akan membahas mengenai konsep pendidikan karakter di lingkungan keluarga. Melihat luasnya bahasan pendidikan karakter, maka pembahasannya dibatasi pada strategi membangun komunikasi dalam lingkungan keluarga sesuai tuntutan al Quran. Pembahasan mengenai pola komunikasi di lingkungan keluarga menjadi salah satu pembahasan yang penting dalam pendidikan karakter, karena pola komunikasi yang efektif di lingkungan keluarga akan menghasilkan generasi yang berkualitas, yang ditandai dengan lahirnya generasi yang toleran.

\section{Keluarga merupakan} lingkungan terkecil dalam sistem kehidupan social kemasyarakatan. Keluaraga menjadi tempat pembelajaran pertama bagi setiap individu, sebelum akhirnya belajar di sekolah, lingkungan masyarakat, dan tempat bekerja. Berangkat dari keluarga pula, fondasi awal karakter individu ditempa. Berbagai nilai positif ditanamkan oleh orang tua semenjak dini di dalam keluarga. Jika nilai-nilai positif salam dalam proses penanamannya di dalam keluarga, maka berakibat tidak baik bagi individu saat berkembang di lingkungan yang lainnya.

Maraknya kasus kekerasan di lingkungan pendidikan Indonesia, seperti halnya kasus kejadian di
Sampang dimana seorang siswa menganiaya gurunya hanya karena tidak terima ditegur oleh gurunya, atau kejadian di Kalimantan Barat dimana seorang Guru dipukul oleh orang tua siswa yang tidak terima anaknya ditegur oleh guru tersebut semakin menegaskan betapa pentingnya pendidikan nilai yang harus ditanamkan di keluarga. Efek yang lebih luas apabila kondisi seperti ini terjadi terus menerus, maka akan melahirkan terjadi prilaku-prilaku yang sifatnya anti sosial. Maraknya kejadian bullying di kalangan generasi muda, merebaknya prilaku radikal atas nama agama, sampai yang lebih parahnya adalah terjadinya krisis moral yang berujung kepada hancurnya suatu peradaban.

Krisis moral yang terjadi di kehidupan sosial menurut Anis Matta (6 : 2006) ditandai dengan munculnya dua gejala, yakni keterasingan dan tirani. Dalam hal ini, Matta menjelaskan bahwa tirani merupakan gejala rusaknya perilaku sosial. Polarisasi antara dua kelompok begitu jelas terlihat. Kelompok yang kuat muncul menjadi tiran dan kelompok yang lemah menjadi objek tiran. Nilai yang dipakai oleh kelompok tiran adalah nilai kejahatan dan pemaksaan yang mendorong mereka melakukan tindakan tiran, sedangkan pada kelompok lemah menyebar nilai-nilai kehinaan yang 
mematikan semangat perlawanan dan kemajuan. Masyarakat terjebak pada sikap fatalisme yang hanya nrimo dan pasrah dengan keadaan tanpa adanya kemauan untuk bangkit dan merubah keadaan.

Sementara itu keterasingan menandai rusaknya hubungan sosial dan berakibat terpisahnya individu dari kelompok masyarakatnya. Individu bekerja secara fisik dengan masyarakat, namun tidak terjalin keakraban dalam hatinya. Pun hidup di tengah masyarakat, namun tiada kebersamaan dalam hidupnya. Secara perlahan tapi pasti, individu dan masyarakat terbelah dan terpisah. Tiada lagi kepercayaan kepada orang lain dan hilang puka semua dorongan persahabatan.

Sejatinya, UNESCO telah menegaskan 4 pilar pendidikan modern, yakni learning to know, learning to do, learning to be, dan learning to live together. Keluarga sebagai bentuk dari pendidikan informal juga dituntut untuk mampu mengarahkan proses pembinaan di dalamnya mengarah kepada pilar pendidikan tersebut, dimana tujuan akhir dari pendidikan di keluarga adalah supaya individu yang ada disana dapat menerapkan prinsipprinsip hidup bersama (learning to live together). Membangun kehidupan yang toleran, yang sejalan dengan nilai luhur bangsa Indonesia, Bhineka Tunggal Ika.
Untuk membangun lingkungan yang harmonis dan toleran tersebut, salah satunya adalah bagaimana dingun pola komunikasi yang efektif di lingkungan keluarga. Pada akhirnya, komunikasi antara anggota keluarga yang penuh kehangatan, sehingga tercipta rasa saling memiliki, dan saling menghargai diantara anggota keluarga lainnya. Sikap mulia tersebut, apabila menjadi kebiasaan di lingkungan keluarga, akan terbawa dalam kehidupan social bermasyarakat.

Agama Islam, telah menuntun pemeluknya mengenai keluarga mengenai pentingnya menjaga keluarga. Memiliki keluarga yang harmonis, toleran, dan saling menghargai merupakan dambaan setiap orang. Apalagi kalau ketiga karakter tersebut sesuai dengan ajaran agama. Karena itulah, setiap pasangan yang baru menikah, diharapkan menjadi keluarga yang sakinah, mawaddah dan warahmah. Diharapkan bisa membangun keluarga yang penuh kasih sayang, cinta, dan tentram. Hal ini juga dijelaskan dalam Al Quran, "Dan orang orang yang berkata : "Ya Tuhan kami, anugrahkanlah kepada kami isteri-isteri kami dan keturunan kami sebagai penyenang hati (kami), dan jadikanlah kami imam bagi orang-orang yang bertakwa”. (QS Al Furqan : 74) 
Diantara alasan mengapa pasangan dan keturunan yang diminta itu adalah yang dapat menyenangkan hati, adalah supaya kebaikan yang ada dalam keluarga ini bisa diwariskan bukan hanya dalam lingkup keluarga, namun juga dalam lingkup kehidupan social. Sehingga ayat tersebut diakhiri dengan permintaan supaya dijadikan pemimpin bagi golongan yang bertakwa.

Artikel ini disusun dengan tujuan untuk mengetahui bagaimana tuntunan al Quran dalam membangun komunikasi yang dapat menanamkan toleransi di lingkungan keluarga. Diharapkan apabila tergali pola komunikasi tersebut, maka akan terbuka wawasan mengenai luasnya samudera ilmu dalam al Quran, dan secara praktis terbinanya individuindividu toleran yang dapat membentengi diri dari pola piker dan pola sikap yang ekstrim dan radikal.

\section{PEMBAHASAN}

\section{Definisi Toleransi}

Menurut Malik Thoha (2005 : 212), istilah Tolerance (toleransi) merupakan istilah modern, dilihat dari segi nama, ataupun kandungannya. Istilah tersebut lahir di Barat, di bawah situasi dan kondisi politik, sosial dan budayanya yang mempunyai kekkhasan tersendiri. Secara etimologi, toleransi berasal dari bahasa Latin, yakni tolerantia, yang artinya kelonggaran, kelembutan hati, keringanan dan kesabaran. Istilah toleransi berkembang dengan sangat baik di Eropa, terutama pada masa revolusi Perancis. Hal ini terkait erat dengan slogan kebebasan, persamaan dan persaudaraan yang menjadi dasar dan inti dari revolusi Perancis. Ketiga istilah tersebut mempunyai kedekatan etimologis dengan istilah toleransi. Secara umum, istilah tersebut mengacu pada sikap terbuka, lapang dada, sukarela dan kelembutan.

Menurut Kamus Umum Bahasa Indonesia, Toleransi yang berasal dari kata "toleran" itu sendiri berarti bersifat atau bersikap menenggang (menghargai, membiarkan, membolehkan), pendirian (pendapat, pandangan, kepercayaan, kebiasaan, dan sebagainya) yang berbeda dan atau yang bertentangan dengan pendiriannya. Toleransi juga berarti batas ukur untuk penambahan atau pengurangan yang masih diperbolehkan. Secara bahasa atau etimologi toleransi berasal dari bahasa Arab tasamuh yang artinya ampun, maaf dan lapang dada. (Munawir, 1998). Badawi menyebutkan bahwa tasamuh adalah pendirian atau sikap yang termanifestasikan pada penerimaan terhadap berbagai pandangan dan penderian yang beraneka ragam 
meskipun tidak sepakat dengannya. (Bahari, 2010)

Secara terminologi, menurut Umar Hasyim (1978), toleransi yaitu pemberian kebebasan kepada sesama manusia atau kepada sesama warga masyarakat untuk menjalankan keyakinannya atau mengatur hidupnya dan menentukan nasibnya masing-masing, selama dalam menjalankan dan menentukan sikapnya itu tidak melanggar dan tidak bertentangan dengan syaratsyarat atas terciptanya ketertiban dan perdamaian dalam masyarakat. Namun menurut W. J. S. Poerwadarminto dalam "Kamus Umum Bahasa Indonesia" toleransi adalah sikap/sifat menenggang berupa menghargai serta memperbolehkan suatu pendirian, pendapat, pandangan, kepercayaan maupun yang lainnya yang berbeda dengan pendirian sendiri.

Dari berbagai definisi di atas, maka toleransi yang dimaksud dalam artikel ini adalah sikap untuk dapat menerima, menghargai, dan menghormati setiap perbedaan dalam aspek kehidupan, sekalipun tidak setuju dengan hal tersebut.

\section{Teori Komunikasi}

Solihin (2011:24), dengan mengutip Jamaluddin, menyebutkan bahwa komunikasi yang dalam bahasa Inggris Communication, berasal dari bahasa Latin, yakni communication, atau communis yang mempunyai makna sama. Maksud sama disini adalah adanya kesamaan persepsi antara pihak pertama sebagai penyampai dan pihak kedua yang menerima pesan. Secara umum, Al Kalali (1997 : 276) menjelaskan bahwa komunikasi merupakan hubungan yang berkaitan dangan aktifitas bertukar pendapat antara manusia, baik sebagai individu maupun berkelompok.

Ajaran Islam meberikan perhatian besar terhadap pola komunikasi yang dilakukan oleh manusia. Cara berkomunikasi seseorang nenurut islam, dapat menjadi indicator berimannya dia atau tidak, bahkan lebih jauhnya dapat menentukan apakah orang tersebut merupakan orang baik atau tidak. Bukan hanya itu pula, besarnya perhatian ajaran Islam terhadap cara berkomunikasi, dapat menentukannasib seseorang, apakah masuk surga atau tidak. Hal tersebut tergambar dari hadits nabi saw yang diriwayatkan oleh Imam Bukhari (1987 : 115), yang artinya :

Telah bercerita kepada kami Muhammad bin Abu Bakar al Muqaddami, telah bercerita kepada kami Umar bin 'Ali, Ia mendengar dari Abu Hazm, dari Sahal bin Sa'ad dari Rasulullah bahwa Beliau bersabda : "Barangsiapa menjaga dari apa yang ada di janggutnya 
(lisan), dan apa yang ada di antara kedua kakinya (kemaluan), maka aku jamin ia akan masuk surga"

Dalam peran dan fungsinya sebagai makhluk sosial, manusia mempunyai posisi yang lebih baik dan mulia dibandingkan makhluk lainnya. Hal tersebut dikarenakan manusia diberi karunia untuk dapat berbicara dalam berkomunikasi dengan sesamanya. Dengan bekal berbicara tersebut, manusia mempunyai kemampuan untuk membangun interaksi dengan lingkungannya sebagaimana yang dipahami dari surat ar-Rahman (55: 4) tentang al-bayān. Al Shabuni (1981 : 48) menyebutkan bahwa albayān disana bermakna manusia diberikan petunjuk oleh Allah untuk bisa berkomunikasi sehingga dapat menerangkan maksud sesuatu. Sejalan dengan pendapat tersebut, Ibnu Katsir menyebutkan bahwa kata al-bayān pada ayat tersebut mempunyai makna berbicara (alnuthq).

Kemampuan berbicara yang dimiliki oleh manusia mempunyai makna bahwa berarti orang tersebut mempunyai kemampuan berkomunikasi. Berkomunikasi merupakan sarana untuk membentuk saling pengertian dan menumbuhkan persahabatan, toleransi, memelihara kehidupan social, kasih-sayang, menyebarkan pengetahuan, dan menumbuhkembangkan peradaban.
Sekalipun begitu, Jalaluddin Rahmat (2000) menyebutkan bahwa komunikasi juga dapat menyebabkan perselisihan, menghidupkan permusuhan, menanamkan kebencian, merintangi kemajuan, dan menghambat pemikiran. Hal tersebut sekaligus memberi gambaran betapa berkomunikasi bukanlah sesuatu yang gampang begitu saja dilakukan oleh setiap manusia

Secara teoritis, pola komunikasi dibagi menjadi komunikasi intra personal, dan interpersonal. Artikel ini membatasi pembahasan dalam pola komunikasi inter personal di lingkungan keluarga.

3. Tuntunan al Quran mengenai Pembinaan Toleransi melalui Komunikasi Efektif pada Anak di Keluarga Komunikasi dalam perspektif Islam merupakan sebuah system komunikasi yang didasarkan kepada nilai-nilai yang terkandung dalam al Quran dan Hadits sebagai rujukan dan sumber ajaran Islam yang mempengaruhi sikap dan tingkah laku umat islam. Al Qardhawi (1996 : 3) menjelaskan bahwa al Quran dinamakan al - Haq dikarenakan al Quran memiliki makna yang luas dan mendalam, diantaranya adalah (1) al Haq merupakan citra yang luhur, meliputi kebenaran, kebajikan, dan 
keindahan; (2) al Haq bermakna etika timbal balik antara manusia.

Oleh karena itu, komunikasi dalam islam adalah sebuah komunikasi yang dibangun atas dasar etika. Dalam perspektif al Quran (Ilyas, 1996), etika komunikasi dalam al Quran mempunyai lima ciri, yakni (1) Rabbani, (2) manusiawi

Universal, (4) Seimbang,dan (5) Realistik. Kelima ciri tersebut selayaknya mengantarkan manusia kepada jalan yang benar, kesesuaian dengan fitrah manusia, membawa kedamaian bagi kehidupan social, menciptakan ketenangan, dan keamanan dalam kehidupan individu maupun komunal, serta membawa kehidupan yang selamat dan seimbang dunia dan akherat.

Secara umum, al Quran menyimpan tuntunan komunikasi dalam terminology Qaul. Beberapa ayat dalam al Quran secara tersurat menyatakan hal tersebut, yakni :

\section{a. Qaulan Baligha}

Surat an Nisa ayat 63 mempunyai arti

"mereka itulah orang yang sesungguhnya Allah mengetahui apa yang ada di hati mereka, karena itu berpalinglah kamu dari mereka, dan berilah mereka nasehat, dan katakanlah kepada mereka perkataan yang berbekas (Baligh) pada jiwanya"

Pada ayat ini terdapat kata Baligh. Menurut Solihin (2011:45), kata tersebut mempunyai makna sampai, tegas, mengenai sasaran, dan sampai pada tujuan. Quraish Shihab (2002, 468) memberikan kriteria khusus sesuatu dianggap baligh, yakni tertampungnya seluruh pesan dalam kalimat yang disampaikan, tidak bertele-tele, tidak mempunyai pengertian yang kabur, pilihan kosa katanya familier dan tidak asing, kesamaan kandungan dengan gaya bahasa, serta mengikuti aturan tata bahasa.

Dalam penerapannya di lingkungan keluarga, pola komunikasi qaulan baligha mengarahkan komunikasi dibangun dengan fasih, tutur bahasa disesuaikan dengan tingkat pemahaman anak. Pemilihan kosakata tidak asing, dan menyesuaikan tingkat pemahaman anak. Orang tua yang mengajak berkomunikasi dengan anak dengan menyentuh akal dan hatinya sekaligus. Sehingga anak dapat menerima untaian nasihat dan nilai dalam proses berkomunikasi dengan orangtuanya.

\section{b. Qaulan Sadida}

Tuntunan al Quran mengenai komunikasi dengan pola qaulan sadida ada dalam dua ayat, yakni 
dalam QS an Nisa ayat 9 yang artinya:

"dan hendaklah takut (kepada Allah) orang-orang yang sekiranya meninggalkan keturunan yang lemah di belakang mereka yang mereka khawatir terhadap (kesejahteraan mereka). Oleh sebab itu, hendaklah mereka bertakwa kepada Allah, dan hendaklah mereka berbicara dengan tutur kata yang benar"

Serta QS. al Ahzab ayat 70 yang artinya :

"Hai orang-orang yang beriman, bertakwalah kalian kepada Allah, dan hendak berkata dengan prkataan yang benar"

Pada ayat yang pertama, Sayyid Thantawi dalam Shihab (2002 : 338) menyebutkan bahwa ayat tersebut turun dengan maksud ditujukan untuk semua kalangan, karena semuanya diperintahkan untuk berlaku adil, berucap benar dan tepat, dan khawatir dengan apa yang digambarkan di atas. Sejalan dengan hal tersebut, Quraisy Shihab (2002 : 339) juga menyebutkan bahwa amalan shaleh yang dilakukan oleh orang tua dapat menjadi sarana terjaganya harta dan peninggalan orang tua kepada anaknya yang menjadi yatim.
Sedangkan pada ayat kedua dimulai dengan seruan kepada orang yang beriman, sehingga dapat ditarik kesimpulan bahwa perintah berkata dengan benar mempunyai pernan penting dalam menunjukan kadar dan kualitas keimanan seseorang. Implementasi keimanan seseorang dalam ayat ini terwujud dalam bentuk berkata yang benar (Hamka, 1984 : 109), dan juga perkataan yang mendidik, baik dan benar (Shihab, 2002).

Dalam prakteknya, orang tua tidaklah dibenarkan untuk berbohong dalam berkomunikasi dengan anak-anaknya. Orang tua memberikan pengajaran dengan kata-kata yang baik dan benar, sehingga segala apa yang keluar dari mulut orang tua menjadi contoh yang nyata dalam kehidupan anak.

\section{c. Qaulan Kariman}

Tuntunan komunikasi dengan pola qaulan kariman terdapat dalam QS. al Isra ayat 23 yang artinya berbunyi :

"dan janganlah kamu sekalikali mengatakan kepada orangtuamu perkataan "ah" dan janganlah kamu membentak mereka, dan katakanlah kepada mereka perkataan yang mulia"

Al Mawardi (2002 : 35) menyebutkan qaulan karima adalah perkataan dan ucapan yang baik yang mencerminkan kemuliaan. 
Sementara Zuhaili dalam tafsir al Munir berpendapatkan qaulankarima adalah seruan untuk mengucapkan perkataan yang lemah lembut serta dibarengi dengan sikap sopan santun dan penuh tatakrama. Sayyid Quthb (2003 : 318) menyebutkan bahwa sejatinya qaul karim dalam konteks hubungan anak denngan orang tua mereka, dan menjadi tingkatan tertinggi dalam pola komunikasi anak dengan orang tuanya.

Dalam prakteknya, orang tua dapat mengajarkan komunikasi dengan anak melalui aplikai langsung. Orang tua memberikan contoh kepada anaknya dengan cara orang tua tersebut memuliakan orang lain yang lebih tua darinya. Perlihatkan contoh bagaimana seharusnya berkomunikasi dengan orang yang lebih tua, dan biarkan sang anak melihat serta belajar langsung dengannya. Biarkan sang anak untuk melihat betapa mulianya pilihan kata dari kita sebagai orangtuanya dalam memperlakukan orang yang lebih tua, perlihatkan toleransi dan penghormatan secara nyata dalam kehidupannya.

\section{d. Qaulan Maysura}

Terminology Qaulan Maysura terdapatdalam QS. al Isra ayat 28 , yang artinya :

"Dan jika engkau berpaling dari mereka untuk meperoleh rahmat dari
Tuhanmu yang engkau harapkan, maka katakanlah kepada mereka perkataan yang lemah lembut"

Al Maraghi (1993 : 71) menyebutkan bahwa ayat ini berkenaan dengan perintah kepada Rasulullah saw untuk menunjukan sikap yang arif dan bijaksana dalam menghadapi lingkungan keluarga ataupun masyarakat yang keras menentang dakwah beliau, sikap arif dan bijaksana sana tersebut terwujud dalam sikap yang sabar dan tetap mengucapkan perkataan yang manis dan lemah lembut, sekalipun dicemooh dan dihina oleh mereka.

Ayat ini menuntun orang tua untuk senantiasa berkata lemah lembut terhadap anak, sekalipun anak berkata kasar kepadanya. Tetap memperlakukan dengan arif dan bijaksana. Tertanam pemahaman dan permakluman dalam dirinya saat anak mengeluarkan kata-kata kasar dan tidak pantas sekalipun kepadanya. Kata-kata yang keluar merupakan pilihan dengan kata yang yassara, mudah dipahami, ringan dan mudah dicerna anak. Sehingga dengan itu, anak menjadi tertarik dan bersimpati kepada orangtuanya.

\section{e. Qaulan Ma'rufa}

Tuntunan komunikasi dengan pola Qaulan Ma'rufa, dalam QS. an Nisa ayat 5 yang artinya berbunyi : 
"Dan janganlah kamu serahkan kepada orangorang yang belum sempurna akalnya, harta (mereka yang ada dalam

kekuasaanmu)yang dijadikan Allah sebagai pokok kehidupan. Berilah mereka belanja dan pakaian (dari hasil harta itu), dan ucapkanlah kepada mereka perkataan yang baik"

Qaulan ma'rufa sejatinya adalah perkataan yang baik dan menimbulkan rasa damai dan tentram bagi mereka yang mendengarkan. Selain dalam ayat di atas, ada beberapa tempat lagi dimana al Quran menyebut terminology qaulan ma'rufa, yakni QS. al Baqarah : 235; QS. al Ahzab : 32; QS. al Baqarah : 263; dan QS. an Nisa : 8. Ungkapan qaulan ma'rufa berkenaan dengan wanita dan orang yang kurang beruntung dalam kehidupannya. Menurut Shihab (2003 : 85) hal ini dimaksudkan agar setiap orang dapat berkomunikasi dengan pantas, karena perkataan yang pantas dapat membuat hati tentram dan bahagia.

Dalam prakteknya, adakalanya seorang anak mengalami kegagalan dalam kehidupannya. Dalam kondisi seperti itu, maka orang tua diarahkan untuk memberikan kata-kata yang pantas dan memberikan ketenangan kepada anaknya. Bukan kata-kata yang melaha menekan dan menjatuhkan mental sang anak. Berikan motivasi dan pemahaman, bahwa kegagalan itu adalah hal yang biasa, dan mereka yang sukses sejatinya adalah orang yang telah mengalami berbagai kegagalan dalam kehidupannya.

\section{f. Qaulan Layyina}

Tuntunan komunikasi dengan pola qaulan layyina terdapat dalam QS. Thaha ayat 44 yang artinya berbunyi :

"Maka berkatalah kamu
berdua kepadanya dengan
kata-kata yang lemah
lembut, mudah-mudahan ia
akan ingat dantakut"

Ayat ini berkenaan dengan perintah Allah kepada Nabi Musa as dan Nabi Harun as untuk pergi berdakwah kepada Fira'un dengan memilih komunikasi dengan pola qaulanlayyina. Al Maraghi (1993 : 203) menyebutkan bahwa layyina disini bermakna lemah lembut, sehingga kata-kata yang disampaikan dapat menyentuh hati dan menerima kebenaran. Dengan perkataan yang lemah lembut, hati yang keras sekalipun dapat menjadi lembut. Pada garis besarnya, Nabi Musa dan Nabi Harun diperintahkan oleh Allah untuk mengeluarkan kata-kata yang lemh lembut, sopan, dan berkasih saying dalam dakwahnya kepada Fira'un, 
sehingga dengan hal tersebut dapat memperoleh hasil yang positif.

Dalam praktek komunikasi di keluarga, komunikasi dengan pola qaulan layyina ini disampaikan oleh orang tua kepada anaknya dengan cara-cara yang lemah lembut, mengayomi, ngemong, dan memberikan penjelasan secara rasional tentang nilai benar dan salah, atau baik dan buruk. Membuka ruang-ruang diskusi, dan tidak bersifat arogan dalam memutuskan suatu perkara.

\section{SIMPULAN}

Dari uraian yang ditelah disampaikan di atas, maka dapat ditarik simpulan :

1. Al Quran menuntun umatnya untuk berkomunikasi dengan baik dan benar, termasuk dalam lingkungan keluarga;

2. Tuntunan al Quran mengenai pola komunikasi meliputi qaulan baligha, qaulan sadida, qaulan karima, qaulan maysura, qaulan ma'rufa, dan qaulan maysura;

3. Semua pola komunikasi tersebut mempunyai kekhasan tersendiri, namun semuanya mempunyai ciri yang sama, yakni prinsip Rabbani, Manusiawi, Universal, Seimbang, dan Realistik;
4. Keenam pola komunikasi tersebut dapat diterapkan dalam menanamkan sikap toleran kepada anak di lingkungan keluarga.

\section{DAFTAR PUSTAKA}

Abdul Muis, Andi. 2001. Komunikasi Islam. Bandung : PT. Remaja Rosda Karya

Al Bukhari, Muhammad bin Ismail bin al Mughirah. 1987. Shahih Bukhari. Beirut : Dar al Fikr

Al Kalali, Asad. 1997. Kamus Arab - Indonesia. Jakarta : PT. Bulan Bintang

Al Maraghi, Ahmad Mustafa. 1993. Tafsir Al Maraghi. Terj. Babun Abu Bakar, dkk. Semarang : Toha Putra

Al Qardhawi, Yusuf. 1996. Epistemologi al Quran, terj. Cetakan ke - 2. Surabaya : Penerbit Risalah Gusti

El Shultani, Mawardi Labay. 2002. Lidah Tak Bertulang. Jakarta : Al Mawardi Prima

Hamka. 1984. Tafsir Al Azhar. Jakarta : Pustaka Panji Mas

Hasyim, Umar. 1979. Toleransi dan Kemerdekaan Beragama dalam Islam Sebagai Dasar 
menuju Dialoq dan

Kerukunan Antar Umat

Beragama. Surabaya: Bina

Ilmu

Ilyas, Yunahar. 1996. Kuliah

Akhlak. Yogyakarta : LPPI UMY

Munawir, Ahmad Warson. 1998.

Kamus Arab Indonesia al-

Munawir. Yogyakarta: Balai

Pustaka Progresif

Quthb, Sayyid. 2003. Tafsir Fi

Zhilalil Quran, Terj. As'ad

Yasin, dkk. Jakarta : Gema

Insani Press

Rahmat, Jalaluddin. 2000. Psikologi

Komunikasi. Bandung :

Remaja Rosdakarya

Shihab, Quraisy. 2002. Tafsir al

Misbah. Jakarta : Lentera

Hati

Solihin, Amir Mu'min. 2011. Etika

Komunikasi Lisan Menurut Al Quran. Skripsi UIN Syarif Hidayatullah. Tidak diterbitkan

Zuhaily, Wahbah. 1991.

TafsirAlMunir. Beirut : Dar al Fikr 